\title{
Hubungan Antara Motivasi Belajar Dengan Prestasi Belajar Mahasiswa/i Fakultas Kedokteran Universitas HKBP Nommensen
}

\author{
Henny Erina Saurmauli Ompusunggu ${ }^{1}$ \\ ${ }^{1}$ Departemen Biologi Sel dan Molekuler Fakultas Kedokteran Universitas HKBP Nommensen \\ Korespondensi: Henny Erina Saurmauli Ompusunggu, Email: ompusunggu.henny@gmail.com
}

\begin{abstract}
Background: Quality human resource are needed by our country in order to compete with other countries. Indicator of quality human resources graduated from university are good academic achievements. Academic achievement is affected by several factors, such as learning motivation. The aim of this study is to determine the correlation between learning motivation and academic achievements in Medical Faculty of Universitas HKBP Nommensen students.
\end{abstract}

Methods: This research was an analytic study. Respondents of this study were 148 active students of Universitas HKBP Nommensen. Learning motivation skor were obtained using an intrinsic motivation questionnaire and academic achievements were obtained from cumulative achievement index. Pearson test was used to analyzed the correlation between learning motivation and academic achievements of respondents.

Results: Medical Faculty of Universitas HKBP Nommensen students majority had high learning motivation with academic achievments $3,19 \pm 0,28$. There was no correlation between learning motivation and academic achievements in Medical Faculty of Universitas HKBP Nommensen students $(p=0,227)$.

Conclusion: There is no correlation between learning motivation and academic achievements in Medical Faculty of Universitas HKBP Nommensen students.

Keywords: learning motivation, academic achievement

\section{Abstrak}

Latar belakang: Sumber daya manusia yang berkualitas sangat diperlukan negara kita agar dapat bersaing dengan negara lain. Indikator sumber daya manusia berkualitas tamatan perguruan tinggi adalah prestasi belajar yang baik. Prestasi belajar dipengaruhi oleh beberapa faktor, salah satu nya adalah motivasi belajar. Tujuan penelitian ini untuk mengetahui hubungan antara motivasi belajar dengan Prestasi belajar mahasiswa/i di Fakultas Kedokteran Universitas HKBP Nommensen.

Metode: Penelitian ini merupakan penelitian analitik korelasi. Responden penelitian ini sebanyak 148 orang mahasiswa/i aktif Universitas HKBP Nommensen. Motivasi belajar dinilai dengan menggunakan kuesioner motivasi intrinsik dan data prestasi belajar diperoleh dari hasil perhitungan indeks prestasi kumulatif. Uji Pearson digunakan untuk menganalisis apakah dijumpai hubungan antara motivasi belajar dengan prestasi belajar responden.

Hasil: Mahasiswa Fakultas Kedokteran Universitas HKBP Nommensen mayoritas memiliki motivasi belajar yang tinggi dengan IPK 3,19 $\pm 0,28$. Pada penelitian ini didapati hasil tidak ada hubungan antara motivasi belajar dengan prestasi belajar $(p=0,227)$.

Kesimpulan: Tidak ada hubungan antara motivasi belajar dengan prestasi belajar pada mahasiswa Fakultas Kedokteran Universitas HKBP Nommensen. 
Kata Kunci: motivasi belajar, prestasi belajar, IPK.

\section{Pendahuluan}

Sumber daya manusia yang berkualitas sangat diperlukan bangsa kita agar dapat bersaing dengan negara lain. Dalam hal ini, bidang pendidikan berperan sangat penting karena menjadi wadah untuk menghasilkan sumber daya manusia yang berkualitas. Perguruan tinggi merupakan wadah pendidikan yang menjadi tempat akhir bagi seseorang untuk belajar setinggi-tingginya sehingga memiliki kemampuan akademik yang baik dan profesional dibidangnya. ${ }^{1,2}$ Salah satu indikator sumber daya manusia berkualitas keluaran perguruan tinggi adalah perolehan prestasi belajar yang baik oleh mahasiswa/i.2 Prestasi belajar mahasiswa/i setelah mengikuti proses pembelajaran dapat dilihat dari prestasi belajar yang dicapai oleh mahasiswa/i berupa nilai rata-rata Indeks Prestasi Kumulatif (IPK).3,4

Prestasi belajar dipengaruhi oleh beberapa faktor baik secara internal maupun eksternal. Faktor internal yaitu faktor jasmani dan faktor psikologi. Faktor eksternal meliputi kurikulum, dosen, bahan belajar, lingkungan sosial, dan keluarga. Salah satu faktor internal berupa faktor psikologi yang mempengaruhi prestasi akademik adalah motivasi belajar.., 6

Motivasi belajar adalah suatu keinginan atau daya penggerak yang muncul pada diri seseorang yang dapat mempengaruhi kegiatan belajar menjadi lebih efektif sehingga tujuan belajar dapat tercapai. $1,5,7$ Sebagai mahasiswa/i yang nantinya akan menjadi seorang profesional dibidangnya harus memiliki kemampuan utama untuk memenuhi kebutuhan dan tuntutan masyarakat dalam memberikan hasil kerja yang berkualitas. Kemampuan tersebut sangat dipengaruhi oleh motivasi untuk menjadi seorang alumnus yang berkualitas. Mahasiswa/i yang memiliki motivasi kuat akan sangat bersemangat dan pantang menyerah dalam melakukan kegiatan belajar. $^{8}$

Penelitian yang dilakukan oleh Hsar Doe Doh pada 192 siswa di Burma, Thailand didapati hasil tidak adanya hubungan yang signifikan antara motivasi dengan prestasi belajar. ${ }^{9}$ Berbeda dengan hasil penelitian yang dilakukan oleh Korantwi-Barimah dkk terhadap 193 mahasiswa/i di Ghanaian Technical University di Ghana didapati adanya hubungan yang signifikan antara motivasi belajar dengan prestasi belajar. ${ }^{10}$

Di Indonesia juga didapati beberapa penelitian tentang hubungan antara motivasi belajar dengan prestasi belajar. Penelitian yang dilakukan oleh Hidayah terhadap 106 orang mahasiswa/i S1 Fakultas IImu Keperawatan Universitas Indonesia Jakarta melaporkan adanya hubungan yang signifikan antara motivasi belajar dengan IPK. ${ }^{11}$ Hasil yang sama juga diperoleh pada penelitian yang dilakukan oleh Lapu dkk terhadap 49 orang mahasiswa/i FK Undana, yang mendapatkan korelasi yang signifikan antara motivasi dengan prestasi belajar. ${ }^{4}$ Hasil yang sejalan juga diperoleh dari hasil penelitian yang dilakukan Yusuf terhadap 118 orang mahasiswa/i Fakultas IImu Keperawatan Universitas Syiah Kuala Banda Aceh, yaitu didapati adanya hubungan antara motivasi belajar dengan IPK. ${ }^{12}$ Demikian juga dengan hasil yang diperoleh dari penelitian yang dilakukan oleh Simatupang terhadap 61 mahasiswa/i tingkat I Akademi
Kebidanan Bina Husada Tanggerang, didapati adanya korelasi yang signifikan antara motivasi belajar dengan prestasi belajar. ${ }^{13}$ Hal yang sama juga diperoleh dari penelitian yang dilakukan oleh Riezky dan Sitompul terhadap 132 mahasiswa/i Fakultas Kedokteran Universitas Abulyatama, Banda Aceh, didapati adanya korelasi yang signifikan antara motivasi belajar dengan prestasi belajar. $^{6}$

Hasil yang berbeda diperoleh dari penelitian yang dilakukan oleh Lisiswanti dkk terhadap 169 mahasiswa/i FK Universitas Lampung, didapati hasil tidak adanya korelasi yang signifikan antara motivasi belajar dengan prestasi belajar. ${ }^{14}$ Berdasarkan uraian latar belakang di atas, peneliti tertarik untuk melakukan penelitian mengenai hubungan antara motivasi belajar dengan prestasi belajar mahasiswa/i di Fakultas Kedokteran Universitas HKBP Nommensen.

\section{Metode}

Jenis penelitian ini adalah analitik dengan menggunakan desain cross sectional. Pemilihan responden penelitian menggunakan tehnik purporsive sampling, di mana yang menjadi responden pada penelitian ini adalah mahasiswali angkatan 2014, 2015, 2016 di Fakultas Kedokteran Universitas HKBP Nommensen yang bersedia menjadi responden penelitian, didapati sebanyak 148 orang. Motivasi belajar dinilai dengan menggunakan instrumen kuesioner motivasi initrinsik yang terdiri dari 44 pertanyaan, menggunakan skala likert dengan 5 pilihan skala. Kuesioner telah diuji reliabilitas dan didapati nilai Cronbach's alpha 0,82 yang menunjukkan bahwa instrumen ini reliabel dan valid. Dari 44 pertanyaan yang diberikan dalam kuesioner motivasi intrinsik, rentang skor yang dapat dicapai responden adalah 44 - 220, di mana bila skor yang dicapai responden $\leq 132$ maka motivasi belajar responden rendah, bila skor yang dicapai responden $>132$ maka motivasi belajar responden tinggi. Prestasi belajar dinilai dalam bentuk Indeks Prestasi Kumulatif (IPK).

Analisis data dilakukan dengan terlebih dahulu menilai distribusi data skor motivasi dan prestasi belajar dengan uji normalitas Kolmogorov-Smirnov, kemudian dilanjutkan dengan melakukan uji korelasi Pearson untuk mengetahui hubungan antara motivasi belajar dengan prestasi belajar.

\section{Hasil dan Pembahasan}

Penelitian ini dilakukan di Universitas HKBP Nommensen Medan dengan jumlah responden sebanyak 148 orang mahasiswa/i Fakultas Kedokteran Universitas HKBP Nommensen yang terdiri dari 33,1\% mahasiswa/i angkatan 2014, 33,1\% mahasiswa/i angkatan 2015 dan 33,8\% mahasiswa/i angkatan 2016 (Tabel 1).

Hasil penelitian ini menunjukkan bahwa mayoritas responden memilih kuliah di fakultas kedokteran adalah karena cita-cita untuk menjadi dokter $(72,3 \%)$. Akan tetapi ada beberapa responden yang memilih kuliah di fakultas kedokteran karena anjuran orang tua dan ingin membantu orang lain melalui profesinya. Biaya kuliah responden mayoritas berasal dari orang tua sendiri ( $86,5 \%)$, akan tetapi ada beberapa responden yang mendapat beasiswa, di mana 
setelah menyelesaikan studi mereka harus kembali ke daerah asa untuk mengabdi menjadi dokter (Tabel 1)

Dilakukan uji normalitas untuk menilai distribusi data skor motivasi dan prestasi belajar dalam bentuk IPK menggunakan uji

Tabel 1. Karakteristik Responden

\begin{tabular}{lrr}
\hline \multicolumn{1}{c}{ Karakteristik } & n & \% \\
\hline Angkatan & & \\
2014 & 49 & 33.1 \\
2015 & 49 & 33.1 \\
2016 & 50 & 33.8 \\
Alasan Kuiah FK & & \\
Cita-cita & 107 & 72.3 \\
Keninginan orang tua & 16 & 10.8 \\
Lainnya & 25 & 16.9 \\
Sumber Biaya Kuliah & & \\
Orang tua & 128 & 86.5 \\
Sendiri & 2 & 1.4 \\
Beasiswa & 15 & 10.1 \\
Lainnya & 3 & 2.0 \\
\hline TOTAL & 148 & 100 \\
\hline
\end{tabular}

Kolmogorov Smirnova. Hasil uji normalitas prestasi belajar diperoleh nilai $p=0,2(p>0,5)$ maka distribusi prestasi belajar responden penelitian normal (Tabel 2).

Tabel 2. Distribusi Variabel Penelitian

\begin{tabular}{|c|c|c|c|c|c|c|}
\hline \multirow[b]{2}{*}{ Variabel } & \multirow[b]{2}{*}{ Mean } & \multirow[b]{2}{*}{ Median } & \multirow[b]{2}{*}{ SD } & \multicolumn{2}{|c|}{$\mathrm{Cl} 95 \%$} & \multirow{2}{*}{$\begin{array}{c}\text { Uji } \\
\text { Normalitas' } \\
\text { (p) }\end{array}$} \\
\hline & & & & Min & Max & \\
\hline IPK & 3.19 & 3.20 & 0.28 & 2.03 & 3.73 & 0.2 \\
\hline
\end{tabular}

Prestasi belajar responden yang dinyatakan dalam bentuk IPK didapati rentang IPK responden 2,03 - 3,73, dengan rata-rata IPK $3,19 \pm 0,28$. Hasil ini menunjukkan bahwa prestasi belajar responden rata-rata di atas 3,00 yang berarti memiliki prestasi belajar yang baik..

Tabel 3. Distribusi Motivasi Belajar Responden

\begin{tabular}{lrr}
\hline Motivasi Intrinsik & $\mathbf{n}$ & \multicolumn{1}{c}{$\%$} \\
\hline Tinggi & 142 & 95.9 \\
Rendah & 6 & 4.1 \\
\hline TOTAL & $\mathbf{1 4 8}$ & $\mathbf{1 0 0}$ \\
\hline
\end{tabular}

Hasil penelitian ini menunjukkan mayoritas responden memiliki motivasi belajar yang tinggi, dimana skor motivasi belajar responden berada dalam rentang 117-202, dengan rata-rata 162 \pm 16 . Motivasi belajar yang tinggi pada seseorang dapat dilihat dari fokusnya dan tidak mudah menyerah untuk menggapai kesuksesan walaupun menghadapi berbagai kesulitan. Motivasi belajar yang tinggi dapat mengarahkan memberi semangat bagi seseorang untuk tekun dan aktif dalam menjalani proses belajar mengajar, serta memiliki ambisi untuk memperoleh prestasi belajar yang baik. ${ }^{15}$
Hubungan antara motivasi belajar dengan prestasi belajar mahasiswa/i di Fakultas Kedokteran Universitas HKBP Nommensen diukur menggunakan uji Pearson (Tabel 4).

Hasil analisis statistik penelitian ini menunjukkan tidak ada hubungan antara motivasi belajar dengan prestasi belajar $(p=$ $0,227)$. Hasil penelitan ini sejalan dengan hasil penelitian Hsar Doe Doh terhadap 192 siswa di Burma, Thailand, didapati hasil tidak adanya korelasi yang signifikan antara motivasi belajar dengan prestasi belajar. ${ }^{9}$ Sejalan juga dengan hasil penelitian Lisiswanti dkk terhadap 169 mahasiswa/i Fakultas Kedokteran Universitas Lampung, didapati hasil tidak adanya korelasi yang signifikan antara motivasi belajar dengan prestasi belajar. ${ }^{14}$ Berbeda dengan hasil penelitian Hidayah terhadap 106 orang mahasiswa/i S1 Fakultas IImu Keperawatan Universitas Indonesia, didapati hasil adanya hubungan yang bermakna antara motivasi belajar dengan prestasi belajar $(p=0,008) .{ }^{11}$ Demikian juga hasil penelitian Yusuf terhadap 118 orang mahasiswa/i Fakultas IImu Keperawatan Universitas Syiah Kuala Banda Aceh, didapati hasil adanya hubungan antara motivasi belajar dengan Indeks Prestasi Kumulatif (IPK) mahasiswa/i $(p=0,001){ }^{12}$ Hasil yang sejalan juga diperoleh dari penelitian yang dilakukan oleh Simatupang terhadap 61 mahasiswa/i tingkat I Akademi Kebidanan Bina Husada Tangerang, didapati adanya korelasi yang signifikan antara motivasi belajar dengan prestasi belajar. ${ }^{13}$ Hasil penelitian Simatupang tersebut didukung oleh hasil penelitian yang dilakukan oleh Lapu terhadap 49 mahasiswa/i FK Undana dan hasil penelitian Riezky dan Sitompul terhadap 132 mahasiswa/i Fakultas Kedokteran Universitas Abulyatama, Banda Aceh, yang menemukan adanya korelasi yang signifikan antara motivasi belajar dengan prestasi belajar.4,6

Tabel 4. Hubungan Motivasi Belajar dengan Prestasi belajar

\begin{tabular}{lcr}
\hline & \multicolumn{3}{c}{ Prestasi Belajar (IPK) } \\
\hline \multirow{3}{*}{ Motivasi Belajar } & $\mathrm{r}$ & 0.062 \\
& $\mathrm{p}$ & 0.227 \\
& $\mathrm{n}$ & 148 \\
\hline
\end{tabular}

Hasil analisis statistik penelitian ini menunjukkan tidak ada hubungan antara motivasi belajar dengan prestasi belajar ( $p=$ 0,227 ). Hasil penelitan ini sejalan dengan hasil penelitian Hsar Doe Doh terhadap 192 siswa di Burma, Thailand, didapati hasil tidak adanya korelasi yang signifikan antara motivasi belajar dengan prestasi belajar. ${ }^{9}$ Sejalan juga dengan hasil penelitian Lisiswanti dkk terhadap 169 mahasiswa/i Fakultas Kedokteran Universitas Lampung, didapati hasil tidak adanya korelasi yang signifikan antara motivasi belajar dengan prestasi belajar. ${ }^{14}$ Berbeda dengan hasil penelitian Hidayah terhadap 106 orang mahasiswa/i S1 Fakultas IImu Keperawatan Universitas Indonesia, didapati hasil adanya hubungan yang bermakna antara motivasi belajar dengan prestasi belajar $(p=0,008) .{ }^{11}$ Demikian juga hasil penelitian Yusuf terhadap 118 orang mahasiswa/i Fakultas IImu Keperawatan Universitas Syiah Kuala Banda Aceh, didapati hasil adanya hubungan antara motivasi belajar dengan Indeks Prestasi Kumulatif (IPK) mahasiswa/i $(p=0,001) .12$ Hasil yang sejalan juga diperoleh dari penelitian yang dilakukan oleh Simatupang terhadap 61 mahasiswa/i tingkat I Akademi Kebidanan Bina Husada Tangerang, didapati adanya korelasi yang signifikan antara 
motivasi belajar dengan prestasi belajar. ${ }^{13}$ Hasil penelitian Simatupang tersebut didukung oleh hasil penelitian yang dilakukan oleh Lapu terhadap 49 mahasiswa/i FK Undana dan hasil penelitian Riezky dan Sitompul terhadap 132 mahasiswa/i Fakultas Kedokteran Universitas Abulyatama, Banda Aceh, yang menemukan adanya korelasi yang signifikan antara motivasi belajar dengan prestasi belajar. 4,6

Selain motivasi belajar ada beberapa hal lain yang dapat mempengaruhi prestasi belajar seseorang seperti Intelligence Quotient $(I Q)$, bakat, minat, harapan, dan lingkungan. ${ }^{16} / Q$ adalah tingkat kecerdasan seseorang yang dapat diukur, yang sangat mempengaruhi proses belajar seseorang dan juga mempengaruhi peluang seseorang untuk memperoleh prestasi belajar yang baik. ${ }^{14}$ Bakat juga mempengaruhi pretasi belajar. Bakat adalah potensi yang dimiliki seseorang untuk menggapai keberhasilan di masa depan. Apabila bakat seseorang sejalan dengan bidang yang sedang dipelajari, maka akan sangat mudah seseorang mencapai prestasi belajar yang baik. Minat berkaitan dengan ketertarikan yang tinggi terhadap sesuatu. Semakin tinggi minat seseorang dalam proses belajar, akan meningkatkan peluang untuk memperoleh prestasi belajar yang baik. Harapan adalah sesuatu yang dapat meningkatkan dan menggerakkan seseorang ke arah pencapaian tujuan, salah satunya pencapaian prestasi belajar yang baik. Semakin tinggi harapan seseorang, maka seseorang tersebut akan semakin bersungguh-sungguh dalam menggapai harapannya. ${ }^{17}$ Faktor lain yang juga berperan penting mempengaruhi prestasi belajar seseorang adalah faktor lingkungan. Lingkungan sosial yang terdiri dari teman, tenaga pendidik, dan keluarga juga memberi pengaruh besar dalam upaya seseorang untuk mencapai prestasi belajar yang baik. Selain lingkungan sosial, lingkungan fisik yang terdiri dari kampus, sarana prasarana, tempat tinggal (rumah atau kost) juga berperan dalam membentuk suasana belajar yang kondusif. Kondisi ini akan mempengaruhi kenyamanan, konsentrasi dan kedisiplinan seseorang dalam proses belajar dan hal ini tentunya akan sangat berdampak pada prestasi belajar seseorang..$^{16}$

Hasil penelitian ini yang menunjukkan tidak ada hubungan antara motivasi belajar dengan prestasi belajar pada mahasiswa/i Fakultas Kedokteran Universitas HKBP Nommensen bisa disebabkan oleh karena prestasi belajar yang diukur dengan menggunakan nilai IPK yang kurang dapat menggambarkan kualitas belajar mahasiswa/i Fakultas Kedokteran Universitas HKBP Nommensen yang sesungguhnya, dikarenakan sistem akademik yang menerapkan ujian remedial sampai mahasiswa/i lulus. Hal ini yang menjadi kelemahan dari penelitian ini. Perlu dipertimbangkan penelitian berikutnya untuk meneliti hubungan motivasi belajar dengan prestasi belajar yang diukur dari nilai ujian tengah blok dan ujian akhir blok sebelum remedial, karena akan lebih dapat menggambarkan prestasi belajar mahasiswa/i yang sesungguhnya.

\section{Kesimpulan}

Tidak ada hubungan antara motivasi belajar dengan prestasi belajar pada mahasiswa/i di Fakultas Kedokteran Universitas HKBP Nommensen.

\section{Daftar Pustaka}

1. Mayangsari M. Motivasi berprestasi mahasiswa/i ditinjau dari penerimaan orang tua. J Ecopsy. 2013;1: 7-21.

2. Mukti W, Suhartadi S, Yoto Y. Hubungan antara percaya diri dalam belajar dan motivasi belajar dengan prestasi belajar mahasiswa jurusan teknik mesin Fakultas Teknik Universitas Negri Malang. J Tek Mesin. 2017;(1):91105.

3. Tutik Yuliyanti. Kemampuan metakognitif, lingkungan dan motivasi belajar meningkatkan prestasi akademik mahasiswa/i Poltekes Bhakti Mulia. Indones J Med Sci. 2015;2(1):52-9.

4. Lapu E, Tjahyono A, Sidarta S. Hubungan motivasi masuk kedokteran dengan prestasi belajar mahasiswa/i angkatan 2008 FK UNDANA [skripsi]. Universitas Nusa Cendana; 2013.

5. Yuliawan A. Hubungan antara motivasi belajar dan latar belakang pendidikan dengan prestasi belajar mahasiswali. PROFESI. 2016;14(1):1524.

6. Riezky AK, Sitompul ZA. Hubungan motivasi belajar dengan indeks prestasi kumulatif mahasiswa Program Studi Pendidikan Dokter Fakultas Kedokteran Universitas Abulyatama. J Aceh Med. 2017;1(2):79-86.

7. Cynthia L, Martono T, Indriayu M. Pengaruh fasilitas belajar dan motivasi belajar terhadap prestasi belajar mata pelajaran ekonomi siswa kelas XI di SMA negeri 5 Surakarta tahun ajaran 2015/2016 [skripsi]. Universitas Sebelas Maret; 2016.

8. Sobur A. Psikologi Umum. Bandung: Pustaka Setia; 2010

9. Hsar Doe Doh Moo Htoo. Academic motivation and academic achievement of karen refugee students. The Scholar. 2014;6(2):41-46

10. Korantwi-Barimah JS, Ofori A, Nsiah-Gyabaah E, Sekyere AM. Relationship between motivation, academic self-concept and academic achievement amongst students at a Ghanaian Technical University. Int J Hum Resour Stud. 2017;7(1):61-73.

11. Hidayah A. Gambaran motivasi belajar mahasiswa/i Keperawatan Program S1 Reguler yang kuliah sambil bekerja [skripsi]. Universitas Indonesia; 2012.

12. Yusuf M. Hubungan motivasi belajar dengan indeks prestasi akademik mahasiswa Program Studi Ilmu Keperawatan Fakultas Kedokteran Unsyiah Banda Aceh. Idea Nurs J. 2013;4(3):31-124

13. Simatupang E. Hubungan motivasi belajar dengan prestasi belajar pada mahasiswa/i Tingkat I Akademi Kebidanan Bina Husada Tanggerang [skripsi]. Akademi Kebidanan Bina Husada; 2014.

14. Lisiswanti $R$, Sanusi $R$, Prihatiningsih TS. Hubungan motivasi dan prestasi belajar mahasiswa/i kedokteran. J Pendidik Kedokt Indones. 2015;4(1):1-6.

15. Khodijah N. Psikologi pendidikan. Jakarta: PT. Raja Grafindo Persada; 2014.

16. Wahab R. Pisikologi Belajar. Jakarta: PT. Raja Grafindo Persada; 2016. 1921.

17. Danarjati DP, Mutiadi A, Ekawati A. Psikologi Pendidikan. Yogyakarta: Graha IImu; 2014. 28. 